\title{
EFFECT OF WATER IRRIGATION QUANTITY AND COMPOST RATES ON SOME WHEAT VARIETIES UNDER SANDY SOIL CONDITIONS OF WEST DELTA REGION CONDITIONS. \\ Harb,O. M. S. ${ }^{1}$; G. H. Abd El -Hay ${ }^{1}$; M. A. Hager ${ }^{1}$; M.K.Hassanien ${ }^{2}$ and M. M. Abou El-Enin ${ }^{1}$ \\ 1. Agronomy Dep., Fac. of Agric., Al-Azhar Univ., Cairo, Egypt \\ 2. Central Laboratory For Agricultural Climate, ARC. , Giza, Egypt. ABSTRACT
}

Two field experiments were performed in EL-Husain farm, Giza governorate under the condition of sandy soil during 2009/2010 and 2010/2011 seasons, to study the impact of three amount of water irrigation 60,70 and $90 \%$ from evapotranspiration rate $\left(1461 \mathrm{~m}^{3}\right)$ and three compost rates 2,4 and 6 ton/fad. on some growth, yield and its components of two wheat varieties (Sakha 93 and Gemmeiza 9).

Results of the two seasons showed that ,by increasing the water irrigation amount from 60 to 70 or $90 \%$ of the evapotranspiration $\left(1461 \mathrm{~m}^{3}\right)$ led to gradually significant increases for leaf area/plant, dry weight /plant, No. of spikes $/ \mathrm{m}^{2}$, weight of grains /spike, No. of grains/spike, weight of 1000 grains, grain yield /fad. and harvest index .Compost rates had significant impacts on previous characteristics, during the two experimental seasons. The best compost rate was (6 ton/fad) which gave the best results for these traits as compared with the lowest rate ( 2 ton/fad).

Results revealed that, Gemmeiza 9 wheat variety exceeded Sakha 93 wheat variety significantly for above mentioned measurements during the two seasons.

As for the first and second order interactions between the tested factors, results in the two trial seasons revealed that, most of the interactions had significant effects on that character. It wealthy mentions that significant interaction effect was found between the three factors under testing during the two seasons. The highest values for previous characters were obtained by sowing Gemmeiza9 with adding irrigation quantity of $90 \%$ from evapotranspiration and practicing 6 ton compost per fad.

\section{INTRODUCTION}

Wheat is the most important cereal crop as stable food grain in Egypt, where the local production is not sufficient to supply the annual demand of the increasing population, this caused gap between production and consumption. Hence, increasing wheat production is the most important possibility for reducing the wheat gap and reach self sufficiency of wheat production.

To achieve the obvious aim, it could be realized by two ways: First: expanding the area sown second: improving the yield per unit area sown. Wheat areas in sandy soils have gradually increased over the last few years, du to the limitation of agricultural land in the old valley. Sandy soils are very much considered in the plain of horizontal expansion in Egypt. Such soils are characterized by their bulk density and low values of native nutrient content and the high leaching losses of applied fertilizers and water irrigation.

Acton and Gregorich (1995) pointed that the application of compost as organic matter to such soil is desperately needed, to increase soil nutrients and minimize nutrient loss due to leaching, as well as improve moisture holding capacity of sandy soil. 
Ibrahim et al.(1996) studied the effect of irrigation regime on yield of wheat. Results demonstrated that plant height, flag leaf area, No. of tillers and spikes $/ \mathrm{m}^{2}$, No. of grains/spike, weight of 1000 grain, straw and biological yields were significantly decreased by exposing wheat plants to water stress.

Sadek and Abo-Warda(1998) found progressive and significant increase in grain yield ,1000-grain weight and No. of grains/spike with increasing the amount of water applied under the condition of sandy soil (2080, 3330 and $4580 \mathrm{~m}^{3} / \mathrm{ha}$.).

EL-Hinnawy (1999) examined seven wheat genotypes under these moisture regimes (irrigation at 25,50 and $75 \%$ depletion of soil available water. Results indicated that, moisture more than $50 \%$ depletion of soil available water reduced grain yield.

To overcome the sandy soils problem, it requires great efforts to improve its hydro-physical properties, as well as its productivity.

El-Sayed et al. (2000) found that the tested wheat cultivars Gemmeiza 5, 7, and 9 showed significant variations in all studied traits. Gemmeiza 9 surpassed the other two cultivars in number of spikes $/ \mathrm{m} 2$, number of grains/spike, grain weight/spike, 1000- grain weight, grain and straw yields/fed followed by Gemmeiza 7.

Lewandowski (2002) clarified that organic mater increases the nutrient holding capacity of soil .So; it is a pool of nutrients for plants. Organic matter binds nutrients, preventing them from becoming permanently unavailable to plants.

Matter et al. (2007) reported that grain yield of wheat cultivar Sakha93 increased by using organic fertilizer. The highest wheat grain yield was obtained with treatment consisted of 1.2: 0.66: 1.5: 2.5 ton/fad. from farmyard manure, chicken manure, town red use and sewage sludge, respectively.

Zeidan et al. (2009) found that significant differences were detected among the three wheat cultivars in all characters during both seasons and their combined. Sids-1 cultivar was superior and gave the highest value of all studied characters followed by Giza-168 while Sakha-93 showed the lowest values in all studied characters.

This investigation was carried out, to find out the effect of water irrigation quantity and organic fertilizer (compost) rates on growth, yield and yield components of wheat.

\section{MATERIALS AND METHODS}

Two field experiments were carried out during two successive growing seasons of 2009/2010 and 2010/2011 at Al- Husain farm - kilo 64 Cairo Alexandria desert province of Giza governorate, Egypt to investigate the effect of irrigation water quantity and compost rates on growth and yield of two wheat cultivars under the condition of fixed sprinkler irrigation system in sandy soil.

\section{Tested agricultural factors:}

A - Water irrigation quantity:

60,70 and $90 \%$ from evapotranspiration rate $\left(1461 \mathrm{~m}^{3}\right)$ which determined according to Irri-Clac program in Central Laboratory For Agricultural Climate, ARC. , Giza, Egypt. 
B - Compost fertilizer rates: 2, 4 and 6 ton per fadden.

C - Wheat varieties:

The varieties of wheat (Tritium aestivum, L.) tested in this study were:

1- Sakha-93 which is characterized by resistance to rust disease, and salinity.

2- Gemmeiza-9 (V2) which is characterized by resistance to rust disease, echoes and drought, also it enjoys high productivity and quality in central and south Delta and the newly reclaimed soils.

Soil samples were collected at experimental site for two seasons to depth of 30,60 and $90 \mathrm{~cm}$.before sowing for chemical and mechanical analysis which recorded in Tables (1 and 2) respectively, which determined according Page et al. (1982) While Chemical analyses for compost fertilizer are given in Table (3). Regarding with the analysis results for water irrigation sample is given in Table (4).

Table (1): Chemical analysis of soil in at experimental site.

\begin{tabular}{|c|c|c|c|c|c|}
\hline \multirow{2}{*}{ season } & Depth & PH & EC & Total N & Organic \\
\cline { 2 - 6 } & $\mathbf{( C m})$ & $(\mathbf{1 : 2 . 5})$ & $(\mathbf{p p m})$ & $(\mathbf{p p m})$ & Matter $(\%)$ \\
\hline \multirow{3}{*}{$2009 / 2010$} & $30 \mathrm{~cm}$ & 8.4 & 512 & 20 & 0.2 \\
\cline { 2 - 6 } & $60 \mathrm{~cm}$ & 8.3 & 192 & 30 & 0.35 \\
\cline { 2 - 6 } & $90 \mathrm{~cm}$ & 8.2 & 179.2 & 10 & 0.69 \\
\hline \multirow{3}{*}{$2010 / 2011$} & $30 \mathrm{~cm}$ & 8.2 & 568 & 23 & 0.47 \\
\cline { 2 - 6 } & $60 \mathrm{~cm}$ & 8 & 375 & 41 & 0.57 \\
\cline { 2 - 6 } & $90 \mathrm{~cm}$ & 8.1 & 206 & 15 & 0.8 \\
\hline
\end{tabular}

Table (2): Mechanical analysis of soil experimental site.

\begin{tabular}{|c|c|c|c|c|c|}
\hline \multirow{2}{*}{ Seasons } & $\begin{array}{c}\text { Sample } \\
\text { Depth }\end{array}$ & \multicolumn{3}{|c|}{$\%$} & \multirow{2}{*}{ Texture } \\
\cline { 2 - 5 } & $(\mathbf{C m})$ & clay & sand & silt & \\
\hline \multirow{3}{*}{$2009 / 2010$} & $30 \mathrm{~cm}$ & 5.28 & 84.72 & 10 & Loamy sand \\
\cline { 2 - 6 } & $60 \mathrm{~cm}$ & 2.32 & 95.68 & 2 & Sand \\
\cline { 2 - 6 } & $90 \mathrm{~cm}$ & 4.32 & 93.68 & 2 & Sand \\
\hline \multirow{3}{*}{$2010 / 2011$} & $30 \mathrm{~cm}$ & 6.7 & 83.3 & 10 & Loamy sand \\
\cline { 2 - 6 } & $60 \mathrm{~cm}$ & 4.2 & 93.4 & 2.4 & Sand \\
\cline { 2 - 6 } & $90 \mathrm{~cm}$ & 5.3 & 91.6 & 3.1 & Sand \\
\hline
\end{tabular}

Table (3): Chemical analysis for compost fertilizer sample.

\begin{tabular}{|c|c|c|c|c|c|c|}
\hline \multicolumn{4}{|c|}{ Micronutrients(ppm) } & \multicolumn{3}{|c|}{ Macronutrients (\%) } \\
\hline $\mathrm{Fe}$ & Mn & $\mathrm{Zn}$ & $\mathrm{Cu}$ & $\mathbf{N}$ & $\mathbf{P}$ & $\mathrm{K}$ \\
\hline 776 & 534 & 52 & 18 & 0.76 & 0.11 & 1.14 \\
\hline \multicolumn{5}{|c|}{$0 . C \%$} & \multicolumn{2}{|c|}{$\mathrm{C} / \mathrm{N}$} \\
\hline \multicolumn{2}{|c|}{9.7} & \multicolumn{3}{|c|}{16.7} & \multicolumn{2}{|c|}{12.76} \\
\hline
\end{tabular}

Table (4): the analysis results for water irrigation sample:

\begin{tabular}{|c|c|c|c|c|c|c|c|c|c|c|}
\hline \multirow[t]{2}{*}{ Seasons } & \multirow[t]{2}{*}{$\mathrm{EC}(\mathrm{ppm})$} & \multirow[t]{2}{*}{ PH } & \multicolumn{4}{|c|}{$\begin{array}{c}\text { soluble anions } \\
\text { (m.moq/L) }\end{array}$} & \multicolumn{4}{|c|}{$\begin{array}{c}\text { soluble cations } \\
\text { (m.mog/L) }\end{array}$} \\
\hline & & & $\mathrm{CL}^{-}$ & SO4- & CO3 & $\mathrm{HCO3}$ & $\mathrm{Ca}^{++}$ & $\mathbf{M g}^{+}$ & $\mathrm{Na}^{+}$ & $\mathrm{K}^{+}$ \\
\hline & & & 24.44 & 10.54 & & 2 & 19 & 11.5 & 18.5 & 0.22 \\
\hline $2010 / 2011$ & 3436 & 7.9 & 37.8 & 13.61 & 0.5 & 2.28 & 28 & 13.7 & 21.8 & 0.27 \\
\hline
\end{tabular}

Experimental field included eighteen treatments which were the combination of three levels of water irrigation quantity, three rates of compost fertilizer and two wheat varieties. A split- split plot design with three replicates 
Harb,O. M. S. et al.

was used, the main plots were randomly devoted to the irrigation quantity treatments and the sub plots were randomly devoted to the compost fertilizer rates while the sub-sub plots were randomly assigned to the two wheat varieties and then combined analysis was used for two seasons.

The experimental plot area was $22 \mathrm{~m}^{2}(11 \times 2 \mathrm{~m})$. There were 8 rows in each plot spaced $20 \mathrm{~cm}$ apart. The planting date was at 24/11/2009 for the first season, while it was at 26/11/2010 in the second season. Calcium super phosphate $\left(15.5 \% \mathrm{P}_{2} \mathrm{O}_{5}\right)$ was added before sowing at the rate150 $\mathrm{kg}$. /fad. As well as, potassium was added as potassium sulphate $(48 \%)$ at the rate of 100 $\mathrm{kg} / \mathrm{fad}$. The Seeding rate was $60 \mathrm{~kg}$. /faddan in two seasons. Nitrogen was added as ammonium sulfate $(20.6 \%)$ at the rate of $360 \mathrm{~kg}$. /fad. in five equal portions throw the irrigation system. The first, second, third, fourth and fifth portion were added after 14, 22, 34, 42 and 54 day from sowing, respectively. Irrigation treatments started after 30 day of planting date, the plots were irrigated at each 4 days interval as spring irrigation. The two wheat varieties were harvested after 147 day of planting date in 2009/2010 season and after 159 day in 2010/2011 season.

\section{Studied attributes:}

A. Growth attributes: a random sample of ten plants were taking at 90 days after sowing for tetermined traits as follows:

1.leaf area per plant $\left(\mathrm{cm}^{2}\right)$ which was calculated as follows formula described by Voldeng and Simposn (1967): (Length $x$ maximum width $\times 0.79$ )

2. Dry weight per plant $(\mathrm{gm})$ which was estimated after drying the plant to temperature $105-110^{\circ} \mathrm{C}$ for 24 hours.

B. yield components:

1. Number of spikes per $\mathrm{m}^{2}$ was determined from a random sample of one $\mathrm{m}^{2}$ taken from each plot.

2. Weight of 1000 grain (gm) was obtained from the weight of 1000 grain taken at random from each plot.

3. Number of grains per spike: was recorded from a sample of 10 main spikes collected from 10 randomly selected plants in each plot.

4. Weight of grains per spike (gm).

C. Yield:

1. Grain yield per faddan $(\mathrm{kg})$ which determined from all plants in each plot. and converted to $\mathrm{kg} / \mathrm{fad}$.

2. Harvest index $(\mathrm{HI})$ was calculated as: $\mathrm{HI}=$ Grain yield (fad.) /Total Biological yield (fad) ${ }^{*} 100$.

Statistical analysis: All data were exposed to the proper statistical analysis according to Gomez and Gomez (1984). The mean values were compared at $5 \%$ level of significance using least significant differences (L.S.D) test.

\section{A- Effect of irrigation treatments:}

\section{RESULTS AND DISCUSSION}

Results of the combined analysis for the two experimental seasons of 2009/2010 and 2010/2011.presented in Tables 5 and 6, indicate that irrigation treatments had significant effect on wheat leaf area/plant, dry weight /plant, No. of spikes $/ \mathrm{m}^{2}$, weight of 1000 grains, No of grains/spike ,weight of grains /spike, grain yield/fad. and harvest index were increased 
significantly by $(57.09 \%), \quad(56.98 \%), \quad(24.16 \%), \quad(18.78 \%)$, $(15.38 \%)$, $(63.33 \%),(47.86 \%)$ and $(29.03 \%)$ respectively by adding water irrigation at the rate of $90 \%$ from evapotranspiration (ET)as compared with the application of $60 \%$ from ET which awarded the lowest values for that treats during experimental seasons. These results may be due to water defect during either of vegetative and pre-flowering stages which led to decrease water supply and nutrients which led to decrease leaf area /plant and dry weight/plant furthermore containing of water lack starting from developing flowers primordial till ovules fertilization may be led to the low appearance of florets primordial and decrease fertile flowers which in turn reduced No. of grains/spike, economic yield /fad. and harvest index, but under the condition of $90 \%$ of ET may be increased nutrient uptake and adequate supply of them to wheat plants for proper growth and metabolic process. These results also confirmed by Ibrahim et al. (1996) and Sadek and Abo-Warda(1998).

\section{B-Effect of compost fertilizer rates:}

With regard to compost fertilizer rates as organic matter, results of the previous studied characters recorded in Tables 5 and 6 , reveal that adding compost at the rate of 6 ton/fad. led to significantly increase all the values of the previous studied characters, as compared with the lowest rate of 2 ton/fad. By adding 6 ton/fad. led to gain the greatest values for leaf area /plant (277.6 $\mathrm{cm}^{2} /$ plant), dry weight /plant (14.2 gm), No. of spikes $/ \mathrm{m}^{2}(327)$, weight of 1000 grains (44.8 gm), No. of grains/spike (78.0), grain yield (1765 /fad $(\mathrm{kg})$, weight of grains/spike $(4.5 \mathrm{gm})$ and harvest index (0.38). These results may be attributed with increase the addition of compost rate to 6 ton/fad. increased the exchangeable capacity of sandy soil, also may be led to increase the collecting of soil particles to improve its water holding capacity and its action exchange capacity. Similar results were obtained by Acton and gregorich (1995) and Lewandowski (2002).

\section{C-Variance between varieties:}

Results presented in Tables 5 and 6, reveal that wheat varieties (Sakha 93 and Gemmeiza 9) were significantly differed in its leaf area/plant, dry weight/plant, No. of spikes/plant, grain weight/plant, No. of grains/spike, 1000 grain weight, grain yield/fad. and harvest index also, Gemmeiza 9 wheat variety excelled Sakha 93 wheat variety for above mentioned measurements during the experimental seasons due to Gemmeiza 9 wheat variety characterized by resistance to rust disease, echoes and drought as well as it enjoys high productivity and quality in newly reclaimed soils as compare Sakha 93 wheat variety. This results confirmed by El-Sayed et al. (2000) and Zeidan et al. (2009).

\section{E- The interaction effect of factors under study:}

Irrigation treatments $\mathrm{x}$ compost rates interaction had significant effect on leaf area/plant, dry weight/plant, No. of spikes/plant, 1000 grain weight, grain weight/plant, No. of grains/spike, grain yield/fad. and harvest index in the experimental seasons. Results revealed that all above mentioned measurements gradually increased by increasing the quantity of water irrigation from $60 \%$ to $70 \%$ and $90 \%$ of evapotranspiration rate of wheat under all compost rates under study. 
Harb,O. M. S. et al.

5

852 
J. Plant Production, Mansoura Univ., Vol. 3 (5), May, 2012

6

853 
Improved the utilization of the high quantity of water irrigation which reflected to increase the above mentioned traits. Results also revealed that wheat varieties tested significantly differed under the irrigation levels tested. Gemmeiza-9 wheat variety scored the greatest values for the above mentioned characters through all irrigation levels as compared with Sakha 93 under the effect of the same irrigation treatments during the experimental seasons.

As for compost rates $\mathrm{x}$ wheat varieties interaction effect results in Tables 5 and 6 show significant measured characters during the two seasons. Gemmeiza- 9 wheat variety showed its superiority under the condition of each of 2 or 4 or 6 ton compost /fad.

Regarding to the second order interaction irrigation $x$ compost $x$ wheat varieties. Results in Tables 5 and 6 reveal that Gemmeiza-9 wheat plants utilized the greatest amount of water irrigation at the level of $90 \%$ of evapotranspiration rate under the condition of 6 ton compost/fad. get the significant greatest values of leaf area/plant, dry weight/plant, No. of spikes/plant, 1000 grain weight, grain weight/plant, No. of grains/spike, grain yield/fad. and harvest index as compared with the other of this interaction treatments during the experimental seasons.

\section{REFERENCES}

Acton, D.F. and L.J. Gregorich (1995).Understanding soil health. In: Acton, D.F., and GREGORICH, I.j.(EDS.) the health of our soil " Agric. And Agric-Food, Canada.

EL-Hinnawy, H.H. (1999). Phenotypic stability analysis for grain yield and some quality traits of wheat under three moisture regimes .J.Agric.Sci.Mansoura Univ., 24(10):5375-5384.

El-Sayed, M.A.A.; M.F. El-Krmany and A. Abo Ellil (2000). Effect of irrigation and nitrogen fertilizer on yield and yield components of some wheat cultivars. Al-Azhar J. Agric. Res. 32, $73-88$.

Gomez, K.A. and A.A. Gomez (1984).Statistical Procedures for Agricultural Research.2 $2^{\text {nd }}$ Ed.Wily, New York.

Ibrahim , M.E. ;S.E. Esmail and F.M. Dawoud (1996 ). Effect of irrigation regime, N.P. fertilization on yield, quality and rate of water loss from excised leaves as indicator to drought resistance in wheat. J.Agric. Res. Tanta. Univ. 22 (1): 1-22.

Lewandowski, A. (2002).Soil manager.Organic matter. Bu-07402. Regents of the Univ. of Minnesota.

Matter, K. M. ; K. F. Moussa; S. A. H. El-Naka and Marwa, A. Ali (2007).Effect of some soil organic amendements on the productivity of sandy soil. Zagazig J. Agric Res., 34 (2): 225-247.

Page, A.L; Miller,R.H and Keeny,D.R.(1982).Methods of soil analysis. Part 2.Soil Sci.Soc.Amer.Inc.Madison,Wisconin,USA.

Sadek, Eman M.M.andA.M.A.Abou-Warda(1998). Water and nitrogen use efficiency and their effect on grain yield of wheat .Annual Coordination meeting 8-11 september, Field Crops Res.Inst Agric.Res. Center, Giza, Egypt. 
Volding , H.D. and G.M. Simpson (1967). Leaf area as indicator of potential grain yield in wheat. Canadian J. Plant Sci. 47:359-365.

Zeidan, E.M.; I. M. ABD El-Hameed; A. H. Bassiouny and A.A.Waly (2009). Effect of irrigation intervals, nitrogen and organic fertilization on yield, yield attributes and crude protein content of some wheat cultivars under newly reclaimed saline soil conditions. $4^{\text {th }}$ Conference on Recent Technologies in Agriculture, 2009.

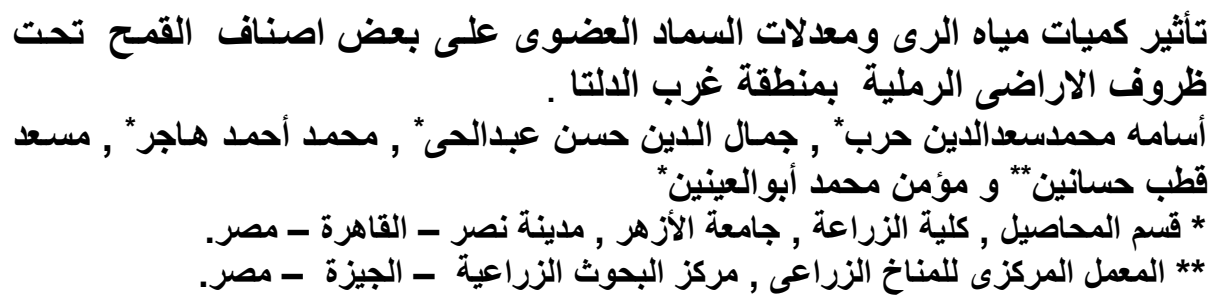

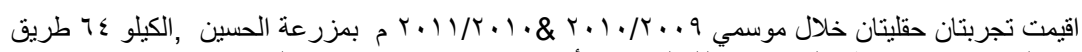

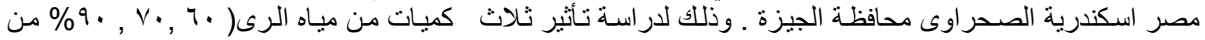

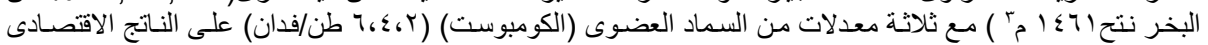

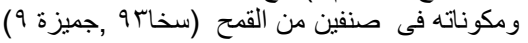

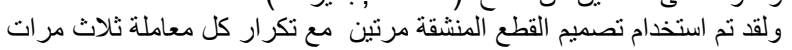

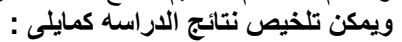

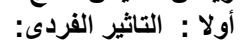

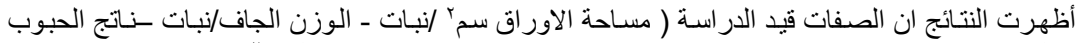

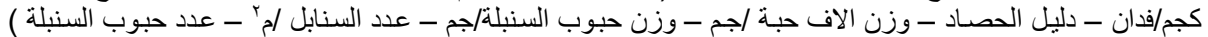

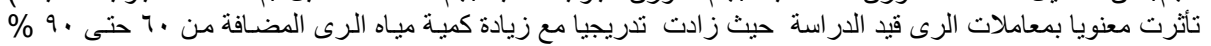

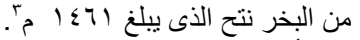

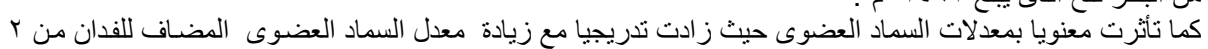

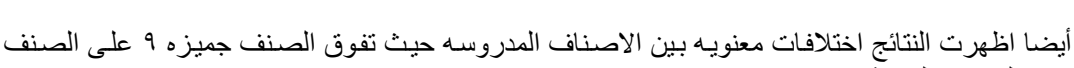

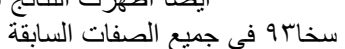
ثانيا : التاثير الثنائى

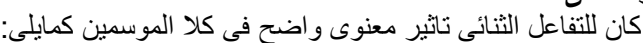

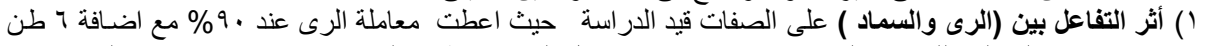

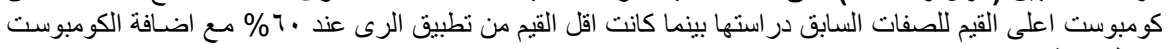

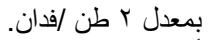

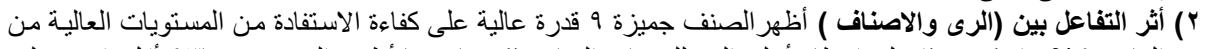

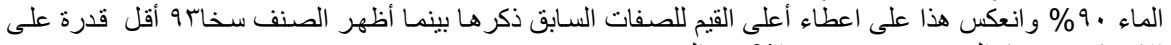

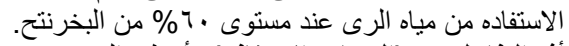

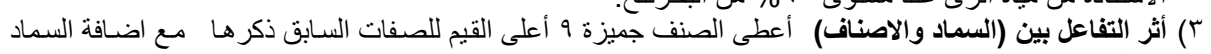

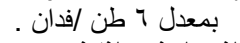
ثالثا: التاثير الثثلاثى :

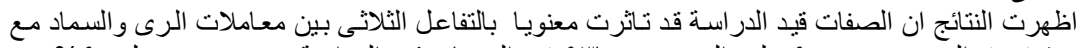

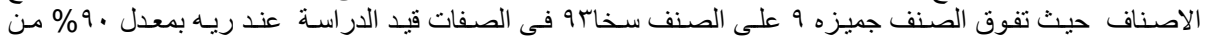
البخرنتح مع اضضافة الكومبوست بمعدل 7 طن الفن الفدان.

كلية الزراعة - جامعة المنصورة قام بتحكيم البحث البخ مدئ كلية الزراعة - جامعة الزراعة الأزهر المنهر أ.د / الغريب / عيد الغريب سيمان 
Harb,O. M. S. et al. 
J. Plant Production, Mansoura Univ., Vol. 3 (5), May, 2012 
J. Plant Production, Mansoura Univ., Vol. 3 (5): 847 - 855, 2012

Table (5): Quantity of water irrigation and compost rates affecting leaf area/plant (cm²), Dry weight per plant (gm), No. of spikes/m2 and weight of 1000 grain (gm) for Sakha93 (V1) and Gemmieza-9(V2) wheat varieties in combined analysis of $2009 / 2010$ and $2010 / 2011$ seasons.

\begin{tabular}{|c|c|c|c|c|c|c|c|c|c|c|c|c|c|}
\hline \multicolumn{2}{|c|}{ Treatments } & \multicolumn{3}{|c|}{ Leaf area /plant ( $\mathrm{cm} 2)$} & \multicolumn{3}{|c|}{$\begin{array}{c}\text { Dry weight (gm) per } \\
\text { plant }\end{array}$} & \multicolumn{3}{|c|}{ No. of spikes/m2 } & \multicolumn{3}{|c|}{ weight of 1000 grain } \\
\hline Irrigation & Compost & V1 & V2 & Mean & V1 & V2 & Mean & V1 & V2 & Mean & V1 & V2 & Mean \\
\hline & C1 ( 2 ton ) & 147.5 & 178.1 & 162.8 & 7.8 & 9.0 & 8.4 & 232 & 246 & 239 & 34.0 & 37.5 & 35.8 \\
\hline \multirow{2}{*}{ I1 (60\%) } & C2 ( 4 ton ) & 155.5 & 206.8 & 181.1 & 8.8 & 10.1 & 9.4 & 258 & 288 & 273 & 36.0 & 38.5 & 37.3 \\
\hline & C3 ( 6 ton ) & 173.9 & 216.8 & 195.3 & 9.5 & 10.7 & 10.1 & 277 & 314 & 296 & 37.0 & 43.5 & 40.3 \\
\hline \multirow[t]{2}{*}{ Mean } & & 158.9 & 200.5 & 179.7 & 8.7 & 9.9 & 9.3 & 255 & 282 & 269 & 35.7 & 39.8 & 37.8 \\
\hline & C1 ( 2 ton ) & 170.5 & 190.5 & 180.5 & 10.0 & 12.4 & 11.2 & 296 & 300 & 298 & 38.5 & 41.0 & 39.8 \\
\hline \multirow[t]{2}{*}{$12(70 \%)$} & C2 (4ton) & 227.7 & 238.2 & 232.9 & 10.8 & 13.2 & 12.0 & 299 & 313 & 306 & 41.5 & 46.0 & 43.8 \\
\hline & C3 ( 6 ton ) & 284.6 & 282.8 & 283.7 & 14.8 & 15.2 & 15.0 & 312 & 342 & 327 & 44.0 & 48.0 & 46.0 \\
\hline \multirow[t]{2}{*}{ Mean } & & 227.6 & 237.1 & 232.3 & 11.9 & 13.6 & 12.7 & 302 & 318 & 310 & 41.3 & 45.0 & 43.2 \\
\hline & C1 ( 2 ton ) & 196.8 & 235.2 & 216.0 & 10.3 & 11.7 & 11.0 & 302 & 322 & 312 & 42.0 & 44.0 & 43.0 \\
\hline \multirow[t]{2}{*}{$13(90 \%)$} & C2 ( 4 ton ) & 274.3 & 280.1 & 277.2 & 15.1 & 15.6 & 15.3 & 321 & 347 & 334 & 43.5 & 44.0 & 43.8 \\
\hline & C3 ( 6 ton ) & 331.1 & 376.3 & 353.7 & 16.0 & 18.9 & 17.4 & 344 & 371 & 358 & 47.5 & 48.5 & 48.0 \\
\hline Mean & & 267.4 & 297.2 & 282.3 & 13.8 & 15.4 & 14.6 & 322 & 347 & 334 & 44.3 & 45.5 & 44.9 \\
\hline \multirow{2}{*}{ G.M. of V. } & & 218.0 & 245.0 & 231.5 & 11.4 & 13.0 & 12.2 & 293 & 316 & 304 & 40.4 & 43.4 & 41.9 \\
\hline & C1 ( 2 ton ) & 171.6 & 201.2 & 186.4 & 9.3 & 11.0 & 10.2 & 276 & 289 & 283 & 38.2 & 40.8 & 39.5 \\
\hline \multirow[t]{2}{*}{ G.M. of C } & C2 ( 4 ton ) & 219.1 & 241.7 & 230.4 & 11.5 & 12.9 & 12.2 & 292 & 316 & 304 & 40.3 & 42.8 & 41.6 \\
\hline & C3 ( 6 ton ) & 263.2 & 292.0 & 277.6 & 13.4 & 14.9 & 14.2 & 311 & 342 & 327 & 42.8 & 46.7 & 44.8 \\
\hline \multicolumn{14}{|c|}{ SD at $5 \%$ for } \\
\hline \multicolumn{2}{|c|}{ Irrigation (I) } & \multicolumn{3}{|c|}{13.4} & \multicolumn{3}{|c|}{0.9} & \multicolumn{3}{|c|}{9.3} & \multicolumn{3}{|c|}{1.8} \\
\hline \multirow{2}{*}{\multicolumn{2}{|c|}{$\begin{array}{c}\text { Compost (C) } \\
\text { Varieties (V) }\end{array}$}} & \multirow{2}{*}{\multicolumn{3}{|c|}{13.4}} & \multicolumn{3}{|c|}{0.9} & \multicolumn{3}{|c|}{9.3} & \multicolumn{3}{|c|}{1.8} \\
\hline & & \multirow{2}{*}{\multicolumn{3}{|c|}{$\begin{array}{l}11.0 \\
22.2\end{array}$}} & \multicolumn{3}{|c|}{0.7} & \multicolumn{3}{|c|}{7.6} & \multicolumn{3}{|c|}{1.4} \\
\hline \multicolumn{2}{|c|}{ Varieties (V) } & & & & & 1.5 & & & 16.2 & & & 3.1 & \\
\hline \multicolumn{2}{|c|}{$\frac{1 \times C}{I \times V}$} & & 18.9 & & & 1.2 & & & 13.2 & & & 2.5 & \\
\hline & & & 18.9 & & & 1.2 & & & 13.2 & & & 2.5 & \\
\hline $\mathrm{Ix}$ & $\mathrm{xV}$ & & 32.9 & & & 2.2 & & & 22.9 & & & 4.3 & \\
\hline
\end{tabular}


J. Plant Production, Mansoura Univ., Vol. 3 (5), May, 2012

Table (6): Quantity of water irrigation and compost rates affecting No. of grains / spike, weight of grains / spike (gm), Grain yield /fad(kg) and harvest index for Sakha93(V1) and Gemmieza-9(V2) wheat varieties in combined analysis of $2009 / 2010$ and $2010 / 2011$ seasons.

\begin{tabular}{|c|c|c|c|c|c|c|c|c|c|c|c|c|c|}
\hline \multicolumn{2}{|c|}{ Treatments } & \multicolumn{3}{|c|}{ No. of grains / spike } & \multicolumn{3}{|c|}{$\begin{array}{l}\text { Weight of grains / spike } \\
(\mathrm{gm})\end{array}$} & \multicolumn{3}{|c|}{ Grain yield /fad(kg) } & \multicolumn{3}{|c|}{ Harvest index } \\
\hline Irrigation & Compost & V1 & V2 & Mean & V1 & V2 & Mean & V1 & V2 & Mean & V1 & V2 & Mean \\
\hline & C1 (2 ton) & 53 & 61 & 57 & 2.10 & 2.50 & 2.30 & 933 & 1271 & 1102 & 0.260 & 0.310 & 0.290 \\
\hline \multirow{2}{*}{ I1(60\%) } & C2 ( 4 ton ) & 64 & 68 & 66 & 2.80 & 3.20 & 3.00 & 1253 & 1341 & 1297 & 0.290 & 0.330 & 0.310 \\
\hline & C3 ( 6 ton ) & 72 & 74 & 73 & 3.40 & 4.00 & 3.70 & 1320 & 1476 & 1398 & 0.320 & 0.340 & 0.330 \\
\hline \multirow[t]{2}{*}{ Mean } & & 63 & 68 & 65 & 2.80 & 3.20 & 3.00 & 1169 & 1363 & 1266 & 0.290 & 0.330 & 0.310 \\
\hline & C1 ( 2 ton) & 60 & 65 & 63 & 3.50 & 3.90 & 3.70 & 1203 & 1420 & 1312 & 0.330 & 0.340 & 0.340 \\
\hline \multirow[t]{2}{*}{$12(70 \%)$} & C2 (4 ton) & 68 & 75 & 72 & 4.00 & 4.20 & 4.10 & 1527 & 1603 & 1565 & 0.350 & 0.360 & 0.360 \\
\hline & C3 ( 6 ton $)$ & 76 & 82 & 79 & 4.40 & 4.70 & 4.60 & 1593 & 1767 & 1680 & 0.370 & 0.380 & 0.380 \\
\hline \multirow[t]{2}{*}{ Mean } & & 68 & 74 & 71 & 4.00 & 4.30 & 4.10 & 1441 & 1597 & 1519 & 0.350 & 0.360 & 0.360 \\
\hline & C1 ( 2 ton ) & 65 & 69 & 67 & 4.00 & 4.80 & 4.40 & 1256 & 1552 & 1404 & 0.350 & 0.390 & 0.370 \\
\hline \multirow{2}{*}{$13(90 \%)$} & C2 ( 4 ton) & 74 & 78 & 76 & 4.80 & 5.00 & 4.90 & 1898 & 2087 & 1993 & 0.410 & 0.410 & 0.410 \\
\hline & C3 ( 6 ton ) & 80 & 84 & 82 & 5.10 & 5.50 & 5.30 & 2146 & 2290 & 2218 & 0.420 & 0.440 & 0.430 \\
\hline Mean & & 73 & 77 & 75 & 4.60 & 5.10 & 4.90 & 1767 & 1976 & 1872 & 0.390 & 0.410 & 0.400 \\
\hline \multirow{2}{*}{ G.M. V. } & & 68 & 73 & 70 & 3.80 & 4.20 & 4.00 & 1459 & 1645 & 1552 & 0.340 & 0.370 & 0.360 \\
\hline & C1 ( 2 ton ) & 59 & 65 & 62 & 3.20 & 3.70 & 3.50 & 1131 & 1414 & 1273 & 0.310 & 0.350 & 0.330 \\
\hline \multirow[t]{2}{*}{ G.M. of C } & C2 ( 4 ton $)$ & 69 & 74 & 71 & 3.80 & 4.20 & 4.00 & 1559 & 1677 & 1618 & 0.350 & 0.370 & 0.360 \\
\hline & C3 ( 6 ton ) & 76 & 80 & 78 & 4.30 & 4.70 & 4.50 & 1686 & 1844 & 1765 & 0.370 & 0.390 & 0.380 \\
\hline \multicolumn{14}{|c|}{ LSD at $5 \%$ for } \\
\hline \multirow{2}{*}{\multicolumn{2}{|c|}{ Irrigation (I) }} & \multicolumn{3}{|c|}{1.2} & \multicolumn{3}{|c|}{0.10} & \multirow{2}{*}{\multicolumn{3}{|c|}{32.4}} & \multicolumn{3}{|c|}{0.018} \\
\hline \multirow{2}{*}{\multicolumn{2}{|c|}{$\begin{array}{c}\text { Compost ( C ) } \\
\text { Varieties (V) }\end{array}$}} & \multirow{2}{*}{\multicolumn{3}{|c|}{1.2}} & \multirow{2}{*}{\multicolumn{3}{|c|}{0.10}} & \multirow{2}{*}{\multicolumn{3}{|c|}{32.4}} & \multirow{2}{*}{\multicolumn{3}{|c|}{0.018}} \\
\hline & & & & & \multirow{2}{*}{\multicolumn{3}{|c|}{0.08}} & 26.5 & & & \multicolumn{2}{|r|}{0.014} & \\
\hline & \multicolumn{3}{|c|}{$\begin{array}{l}1.0 \\
2.1\end{array}$} & & & & & 56.2 & & & 0.031 & \\
\hline \multicolumn{2}{|c|}{$\mathrm{I} \times \mathrm{V}$} & & & & & 0.15 & & & 45.9 & & & 0.025 & \\
\hline & $\mathrm{xV}$ & & & & & 0.15 & & & 45.9 & & & 0.025 & \\
\hline $\mathbf{I x}$ & $\times \mathrm{V}$ & & & & & 0.26 & & & 79.4 & & & 0.044 & \\
\hline
\end{tabular}

